\begin{tabular}{|c|l|}
\hline Title & Behavior of metals in ash melting and gasification-melting of municipal solid waste (MSW) \\
\hline Author(s) & Jung, C. H.; Matsuto, T.; Tanaka, N. \\
\hline Citation & $\begin{array}{l}\text { Waste Management, 25(3), 301-310 } \\
\text { https://doi.org/10.1016/.wasman.2004.08.012 }\end{array}$ \\
\hline Issue Date & 2005 \\
\hline Doc URL & http://hdl.handle.net/2115/13702 \\
\hline Type & article (author version) \\
\hline File Information & wm2005.pdf \\
\hline
\end{tabular}

Instructions for use 


\title{
BEHAVIOR OF METALS IN ASH MELTING AND GASIFICATION-MELTING OF MUNICIPAL SOLID WASTE (MSW)
}

\author{
C.H. JUNG ${ }^{a}$, T. MATSUTO ${ }^{a^{*}}$, N. TANAKA ${ }^{a}$
}

${ }^{a}$ Lab of Solid Waste Disposal Engineering, Graduate School of Engineering Hokkaido University, Kita 13 Nishi 8, Kita-ku, Sapporo, 060-8628, Japan

*Corresponding author. Tel. \& Fax +81-11-706-6827

E-mail address:matsuto@eng.hokudai.ac.jp (T.Matsuto) 


\section{Abstract}

In this study, metal behavior in ash-melting and MSW gasification-melting facilities were investigated. Eight ash-melting and three MSW gasification-melting facilities with a variety of melting processes and feedstocks were selected. From each facility, melting furnace fly ash (MFA) and molten slag were sampled, and feedstock of the ash-melting processes was also taken. For the ash melting process, the generation rate of MFA was well correlated with the ratio of incineration fly ash (IFA) in feedstock, and this was because MFA was formed mostly by mass transfer from IFA and a limited amount from bottom ash (BA). Distribution ratios of metal elements to MFA were generally determined by volatility of the metal element, but chlorine content in feedstock had a significant effect on $\mathrm{Cu}$ and a marginal effect on $\mathrm{Pb}$. Distribution ratio of $\mathrm{Zn}$ to MFA was influenced by the oxidizing atmosphere in the furnace. High MFA generation and distribution ratio of non-volatile metals to MFA in gasification-melting facilities was probably caused by carry-over of fine particles to the air pollution control system due to large gas volume. Finally, dilution effect was shown to have a significant effect on metal concentration in MFA.

Key words : ash-melting, gasification-melting, melting furnace fly ash (MFA), generation rate of MFA, distribution ratio of metal 


\section{Introduction}

In Japan, approximately $78 \%$ of MSW was incinerated and 5.7 million tons of incineration residues were produced in 1999. Fly ash was classified as a "specially-controlled municipal solid waste" in 1991 due to the high leachability of hazardous metals. To cope with this, Japan's Waste Disposal and Public Cleansing (WDPC) Law mandated solid waste incinerators with a capacity of 5 tons per day or larger to stabilize fly ash before final disposal. In 1999, smaller incinerators were added to the list for cases where the dioxin content of fly ash was greater than $3 \mathrm{ng}-\mathrm{TEQ} / \mathrm{g}$.

For stabilization of incineration fly ash, vitrification, solidification with cement, stabilization using chemical agents, and leaching with acids and other solvents are designated methods by the WDPC law. Among these, vitrification is preferred by many municipalities due to volume reduction of residues to landfill, decomposition of dioxins, reuse of molten residue, and reduction of metal leachability. The number of vitrification facilities has increased rapidly since dioxin was added to the criteria for "specially controlled waste" in 1999. While this process was added in a conventional incinerator as a post-treatment of incineration residue, state-of-the-art incinerators called the "gasification-melting system" have also been increasing in number. This system integrates a gasification process in lower temperature and oxygen condition and melting process of residual solid matters. In both the ash-melting and gasification-melting processes, the primary products are molten slag and fly ash, in which metal is distributed similarly between bottom ash and fly ash in the incineration process (Jung, et al. 2003).

There are some requirements for these output materials in terms of environmental impact or resource recovery. (i) Higher distribution of metals to slag : low metal contents in fly ash are preferred for stabilization and landfilling, and metals are stabilized in slag. (ii) 
Higher distribution of metals to fly ash : high metal content in fly ash is preferred for metal recovery, and low content in slag is required for safe reuse as construction materials. Although these two requirements are contradictory to each other, it is helpful to understand the behavior of heavy metals in the melting process for both disposal and recycling.

There have been many reports on content of heavy metals in slag and fly ash, but only a few studies have been done on the distribution in a facility (Yoshiie, et al., 2001 ; Takaoka, et al., 1997). These works have been limited to specific metals or facilities. In this present work, therefore, various kinds of melting furnace were selected and investigated to identify metal behavior. Specifically, the following issues are investigated: (i) which metals are selectively transferred to slag or fly ash? (ii) what are the influential factors determining the distribution of metals in ash melting? (iii) how do the ash-melting and gasification-melting processes compare in regard to metal distribution.

\section{Experimental work}

\subsection{Description of melting and gasification-melting facilities for sampling}

In Japan, a variety of melting furnaces have been developed. As of 1999, plasma arc and surface melting furnaces make up about $70 \%$ of existing and planned facilities (Shigaki M., 2000). Taking this situation into account, the following melting facility types were selected for this study: four plasma arc, two surface melting, one electric resistance, and one coke bed. Table 1 shows a general description of each melting facility. The melting temperature in $\mathrm{MC}$ (coke bed) is controlled at a temperature of $1750^{\circ} \mathrm{C}$, which is relatively high compared with those of the other facilities $\left(1300 \sim 1400^{\circ} \mathrm{C}\right)$. MP1 and MP2 receive only bottom ash. MP4 and MR melt fly ash from a fluidized bed incinerator, and 
incombustible residues removed from the bottom of the incinerator were also treated in MR. In MS1, incineration residues from old landfills are treated as well as fly ash and bottom ash. MC melts incombustible residues from a bulky waste shredding facility in addition to fly ash and bottom ash. Amounts of feedstock and output were based on the obtained record in the month when they were sampled. Production of fly ash and slag are shown on a dry basis by determining moisture contents as received in the authors' lab. Fly ash production was measured before ash stabilization, i.e. chelate and cements are not included. The total production rate of ash and slag exceeded $100 \%$ in some facilities. This might be due to errors in weighing. The furnaces of MP1, MP3, MR, and MC are operated in a reducing atmosphere whereas those of MP2, MP4, MS1, and MS2 are in an oxidizing atmosphere according to the EFing survey from operators of facilities.

The gasification-melting system is generally classified into the fluidized bed, shaft, and kiln types. Sampling was performed from each of these three types. In GM1 and GM3, the gasification process is separated from the melting process. The type of gasification process is fluidized bed furnace for GM1, and kiln furnace for GM3. In GM2, both gasification and melting are done in an identical shaft furnace. GM1 and GM2 receive only combustible wastes, while GM3 treats residues from a bulky shredding facility as well as combustible wastes. All three facilities use bag filters for air pollution control. However, GM3 employs two bag filter systems to increase slag production. Particles collected by the first filter are circulated to the melting furnace, and after injection of slaked lime, a second filter removes the salts produced. GM3 will be excluded in the following discussion since production rate of ash and slag as well as metal contents are not comparable with those in GM1 and GM2.

\subsection{Sampling and sample preparation}


The work of sampling was conducted between May and June 2002 except for GM3, in which samples were taken in July 2003. In ash melting processes, feedstock (incineration fly ash [IFA] and bottom ash [BA]) and output products (melting furnace fly ash [MFA] and slag) were taken for analysis. Incombustible and other waste feedstock (IC and others in Table 1) were not sampled. In gasification-melting processes, only output products were sampled.

The sampling work of BA, IFA, MFA, and slag was performed three times a day at 2-h intervals. BA and IFA were taken before being fed to a melting furnace. MFA was sampled before it was treated with a chemical agent and slag was obtained after water quenching. Sample size was five kilograms for BA and slag, and three kilograms for IFA and MFA. BA and slag samples were dried at $105{ }^{\circ} \mathrm{C}$ for $24 \mathrm{hrs}$, ground for $2 \mathrm{hrs}$ in a ball mill and sieved through a $0.5 \mathrm{~mm}$ screen. The materials passing through the screen were mixed well to obtain a composite sample. This was divided into two equal sized samples (sub-samples) for metal element analysis. IFA and MFA were not dried, but pretreated in the same procedure.

\subsection{Analytical technique}

Depending on the elements to be analyzed, different methods were used for sample dissolution. Fifteen metal elements -Al, As, Bi, Ca, Cd, Cr, Cu, Fe, K, Na, Pb, Sb, Se, Sn and $\mathrm{Zn}$ - were analyzed by atomic absorption spectrometry (AAS) after microwave-assisted digestion (CEM, MDS-2000), which is based on SW 846 Method 3052 (by EPA). As and Se were determined by graphite furnace AAS and the other elements were measured by flame AAS (Hitachi A-2000 and Z-8200). 
Silica was determined by a procedure based on the method of cement analysis by Japanese industrial standards (JISR 9101, Methods for chemical analysis of gypsum). Samples were digested in aqua regia $(\mathrm{HCl}: \mathrm{HNO}=3: 1, \mathrm{v} / \mathrm{v})$ for $24 \mathrm{~h}$ and the residue of digestion was burned at $1000 \pm 50^{\circ} \mathrm{C}$ for $1.5 \mathrm{~h}$. Assuming the residue was $\mathrm{SiO}_{2}$, the content of Si was calculated. Chlorine was analyzed by the Mohr method (The Japan society for analytical chemistry, 1994) after digestion in $10 \% \mathrm{HNO}_{3}$ for $2 \mathrm{~h}$ (Kim, et al., 1995).

\section{Results and discussion}

\subsection{Concentration of metal elements}

The concentration of metal elements in feedstock (IFA and BA) and output products (MFA and slag) are summarized in Table 2 and Table 3. In MP1, MP2, and MC, IFA were not treated in a melting furnace, but metal concentrations are shown for comparison. Table 2 (b) presents the ratio of $\mathrm{Ca}, \mathrm{Si}, \mathrm{Cl}, \mathrm{Na}$, and $\mathrm{K}$ (called the five major elements hereafter) in the total sum of metal elements. It was found that the five major elements occupy about $65 \%$ and $53 \%$ on average in IFA and BA, respectively. In MP3, MS1, and MS2, in which both BA and IFA were fed into a melting furnace, metal concentrations in MFA were higher than those in IFA. Concentration ratios of MFA/IFA were As:3.3 25.3, Cd:1.5 9.1, Cu:4.8 8.8, $\mathrm{Pb}: 3.8 \sim 15.1, \mathrm{Sb}: 1.0 \sim 4.0, \mathrm{Se}: 1.8 \sim 2.2, \mathrm{Sn}: 3.7 \sim 25.5$, and $\mathrm{Zn}: 5.2 \sim 6.1$. Metals were also concentrated to MFA in MP4 in which only IFA was treated. But, Al, Cr, Fe, and Si were transferred to slag.

Metal concentrations in MFA from GM1 and GM2 were about 50 to $75 \%$ lower than those in MFA from ash-melting facilities. In GM3, boiler ash was sampled as well as fly ashes from the first and the second bag filters. Most metal elements were found in ash from 
the boiler and the first bag filter, and few metal elements were found in fly ash from the second bag filter. High contents of $\mathrm{Ca}$ and $\mathrm{Cl}$ in the second fly ash were due to the injection of calcium hydroxide $\left(\mathrm{Ca}(\mathrm{OH})_{2}\right)$ after the first bag filtration.

\subsection{Generation rate of MFA}

In melting of incineration residues, the lowered generation rate of MFA is ideal because MFA needs further treatment for stabilization prior to final disposal, i.e. landfilling. When metal recovery is attempted, a low generation rate of MFA is also preferred because the concentration of metal in MFA increases as the generation amount of MFA decreases. Defining the generation rate of MFA as the ratio of the amount of MFA to the total sum of amount of output products (MFA and slag), influential factors on generation rate of MFA were investigated. As shown in Fig. 1, the generation rate of MFA was well correlated with the ratio of IFA in feedstock. In MP4 and MR, fly ash from a fluidized bed incinerator was supplied, so different characteristics of fly ash might lead to the correlation. However, within MFA from stoker type incinerators excluding MP4 and MR, the correlation is statistically significant $(\mathrm{r}=0.86)$. Therefore, it is concluded that the ratio of IFA in feedstock is the primary factor in determining the generation rate. The amount of MFA used in Fig.1 includes calcium hydroxide for flue gas treatment. The amount of the chemical was $16 \sim 36 \%$ of MFA in facilities for which the data were obtained. Therefore, the actual generation rate is smaller than indicated in Fig.1, but the correlation is preserved even when calcium is excluded.

It has been generally considered that the generation rate of MFA increases as the off-gas flow rate of the furnace increases (Kaneko, 1998). In this study, however, no correlation between the generation rate of MFA and off-gas flow rate was found as shown in Fig. 2. 


\subsection{Mass transfer from IFA and BA}

Concerning the MFA generation rate during melting of incineration residues, one may assume that carry-over of IFA with flue gas stream in the furnace increases the production of MFA because IFA is comprised of finer particles compared with BA. Distribution ratio of mass from BA and IFA can be illustrated as in Fig.3. The ordinate (y-axis) is the ratio of element mass in MFA to that in total output products (MFA+slag), and the abscissa (x-axis) is the ratio of element mass in IFA to that in total feedstock. The mass of the five major elements, i.e. $\mathrm{Ca}, \mathrm{Si}, \mathrm{Cl}, \mathrm{Na}$, and $\mathrm{K}$ in feedstock and output products was computed from Table 2 and 3. The value of MS1, MC, and MR, which receives incombustible waste or incineration residues from old landfills as well as BA and IFA, are shown in brackets for reference because total input mass of elements are unknown. In Fig.3, the behaviors of the five major elements are not the same as each other. The distribution ratio of $\mathrm{Ca}, \mathrm{Cl}, \mathrm{Na}$, and $\mathrm{K}$ to MFA increases with the ratio of IFA in feedstock, but the rate of $\mathrm{Ca}$ is lower than the others. In contrast, Si does not transfer to MFA. The different behavior patterns of the elements negate the simple assumption of the carry-over of particles.

Contribution of IFA and BA to MFA will be discussed by using a schematic diagram as shown in Fig. 4. If $100 \%$ of an element in IFA transfers to MFA, the mass transferred to MFA will be on a solid line of the slope 1.0, and if the same goes from BA, the mass will be on a broken line of the slope of -1.0. The sum of mass from both origins provides the actual amount in MFA. From Fig. 4, it is concluded that little transfer of the five major elements from $\mathrm{BA}$ occurs, while $\mathrm{Ca}, \mathrm{Cl}, \mathrm{Na}$, and $\mathrm{K}$ contained in IFA form the major constituents of MFA. From the amount at $\mathrm{x}=0$, where only $\mathrm{BA}$ is received, the distribution ratio of $\mathrm{Ca}, \mathrm{Cl}$, $\mathrm{Na}$, and $\mathrm{K}$ from BA are considered around $10 \sim 35 \%$. Over $95 \%$ of $\mathrm{Si}$ and about $50 \%$ of $\mathrm{Ca}$ in 
IFA are deposited in slag, which partially contributes to the increased concentration of metals in MFA. Volatile characteristics of metal are another reason for increased concentration of metals in MFA. This will be discussed later in 3.5.

MFA generation rates in the gasification-melting system, 30.4\% in GM1 and 31.6\% in GM2, were higher than those in ash-melting facilities. This may be explained by the carry-over of fine particles produced in the gasification process to the bag filter without melting due to the considerable flow rate of gas. According to records in GM1 and GM2, gas volume per output material is ten to fifteen times larger than in ash-melting facilities.

\subsection{Mass balance}

Before distribution of metal elements to MFA and slag in the melting process is discussed, mass balance was checked for ash-melting furnaces. Fig. 5 displays the ratio of metal elements in output products to those in feedstock calculated from Table 2 and 3 for each melting furnace. MS1, MC, and MR facilities were excluded because not all feedstock were analyzed. The ratios for the major elements - $\mathrm{Ca}, \mathrm{Si}, \mathrm{Na}, \mathrm{K}, \mathrm{Fe}, \mathrm{Al}-$ are stable around 1.0. Predominately, the ratios are in the range of 0.5 to 2.0 . Variability of the other elements was probably due to errors in sampling and amounts in feedstock and outputs.

\subsection{Distribution ratio of metal elements to MFA}

Distribution ratio of metals to MFA was defined as the ratio of metal contents in MFA to metal contents in total sum of output products (MFA+slag) and is shown in Fig. 6. Metal elements were arranged in the order of boiling point of their elemental states. Generally, the 
distribution ratio of metal element to MFA increases as the boiling point is lowered, but such a relation is not consistent among metals as shown in Fig. 6.

As for $\mathrm{Cd}$ and $\mathrm{Pb}$, distribution ratios to MFA were almost $100 \%$. The $\mathrm{Cd}$ element is volatile itself, and chlorides of both metals have significantly lower boiling points, namely, $950^{\circ} \mathrm{C}$ for $\mathrm{PbCl}_{2}$ and $960^{\circ} \mathrm{C}$ for $\mathrm{CdCl}$ (The Japan society for chemistry, 1984). Such volatility can explain the high distribution ratio to MFA. The slightly lower distribution ratio of $\mathrm{Pb}$ in MP1, MP2, and MS1 might be due to low chlorine content in feedstock compared to that in the other facilities (Fig. 7 (a)). The effect of chlorine can be also seen on $\mathrm{Cu}$. The content of $\mathrm{Cl}$ in feedstock is well correlated with the distribution ratio of $\mathrm{Cu}$ to MFA as shown in Fig. 7 (b). The distribution ratio of $\mathrm{Cu}$ to MFA is high in MP3, MP4, and MR, in which the content of chlorine in feedstock is high, between $7.2 \%$ and $15.1 \%$. This can be explained by the formation of $\mathrm{CuCl}_{2}$, which is thermally mobile with a boiling point of $993^{\circ} \mathrm{C}$. The atmosphere in the melting furnace influences the distribution ratio of $\mathrm{Zn}$. In an oxidizing atmosphere, zinc orthosilicate $\left(\mathrm{Zn}_{2} \mathrm{SiO}_{4}\right)$ and $\mathrm{Zinc}$ spinell $\left(\mathrm{ZnAl}_{2} \mathrm{O}_{4}\right)$ are formed, which are thermally stable. On the other hand, zinc chlorides formed in a reducing condition are favored for volatilization (Jakob, et al., 1995). About $30 \%$ to $50 \%$ of $\mathrm{Zn}$ in MP4, MS1 and MS2, whose atmospheres are oxidizing, was deposited in slag, while over $80 \%$ of $\mathrm{Zn}$ transferred to MFA in other facilities.

Metals with high boiling points such as $\mathrm{Si}\left(2360^{\circ} \mathrm{C}\right), \mathrm{Al}\left(2470^{\circ} \mathrm{C}\right), \mathrm{Cr}\left(2670^{\circ} \mathrm{C}\right)$, and Fe $\left(2750^{\circ} \mathrm{C}\right)$ were deposited mainly in slag as predicted. The behavior of Se was questionable, i.e. although the metal and chloride have low boiling points, a good correlation was found between $\mathrm{Cl}$ content in feedstock and the distribution ratio to MFA as shown in Fig. 7 (c). The high variability of distribution ratio of $\mathrm{As}, \mathrm{Bi}$, and $\mathrm{Sn}$ was considered to be the result of analytical errors due to low contents. 
For the gasification-melting process, a fluidized bed (GM1) and shaft (GM2) type furnace were compared with ash-melting processes. Most metal elements show similar distribution ratios to ash-melting except for $\mathrm{Si}, \mathrm{Al}, \mathrm{Fe}$, and $\mathrm{Cr}$. Approximately $20 \%$ of $\mathrm{Si}, \mathrm{Al}$, $\mathrm{Fe}$, and $30 \%$ of $\mathrm{Cr}$ were transferred to MFA during gasification-melting of MSW. These are called lithophilic metals with low volatility. Therefore, this resulted from the carry-over or entrainment of fine particles in the gas flow as discussed in 3.3.

\subsection{Behavior of metal elements}

During melting of incineration residues, the behaviors of the major five metal elements, i.e. $\mathrm{Ca}, \mathrm{Si}, \mathrm{Cl}, \mathrm{Na}$, and $\mathrm{K}$, were discussed in a previous chapter (Fig. 3). In Fig. 8, behaviors of metals are illustrated in the same manner as shown in Fig. 3, excluding As, Bi, and Sn due to low accuracy of measurement. Data for MS1, MR, and MC are shown by a white circle for reference because of incomplete input analysis. As a result, the behavior of metal elements can be categorized into three groups : 1) complete volatilization from BA and IFA : $\mathrm{Cd}, \mathrm{Pb}, 2)$ volatilization only from IFA : $\mathrm{Cu}, \mathrm{Se}, 3)$ non-volatile metals : $\mathrm{Al}, \mathrm{Cr}, \mathrm{Fe}$. Volatility of $\mathrm{Zn}$ depends on gas atmosphere, and chlorine content in feedstock affects the behavior of $\mathrm{Cu}$ and $\mathrm{Se}$. The behavior of $\mathrm{Sb}$ was not clearly categorized.

\subsection{Influential factor on volatile metal concentration}

From the viewpoint of the environmental risk of MFA after landfilling or metal recovery from MFA, increasing attention has been paid to the concentration of metal elements in MFA in recent years. There are several of factors that determine metal concentration in MFA. The first one is obviously metal content in feedstock. In the authors' 
previous study (Jung, et al., 2003), shredded residue of bulky waste increased the total amount of metals in fly ash and bottom ash, which are the feedstock in this study. The second factor is distribution between MFA and slag as discussed in 3.5 and 3.6. The furnace atmosphere and chlorine content in feedstock influence distribution for some metals, but volatility of metal element is the dominant characteristic in the distribution. The last factor is the dilution effect. For a constant amount of metal in feedstock, a higher generation rate of MFA makes metal concentration lower as discussed in 3.2. MFA generation rate was determined by the ratio of IFA and BA in feedstock and furnace type (ash-melting or gasification-melting). The incineration planner or operator can efficiently control the concentration of metals in MFA by selecting these factors, and the third factor seems to be practically controllable.

When the total amount of metal is constant in feedstock, the concentration of metal in MFA will be proportional to the reciprocal of MFA generation for highly volatile metals. In Fig. 9, the concentration of $\mathrm{Cd}, \mathrm{Pb}$, and $\mathrm{Zn}$ in MFA are plotted against $1 / \mathrm{r}$, where $\mathrm{r}$ is the generation rate of MFA. A linear relationship between metal concentration in MFA and the reciprocal of MFA generation was found. From Fig. 9, we found that metal concentration was reduced up to about seven times by the dilution effect.

\section{Conclusion}

The main targets of this study were the production rate of MFA (melting furnace fly ash), metal distribution between MFA and slag, and metal concentration of MFA in the melting process of incineration residue or MSW. By investigating eleven facilities, which were different either in their melting process or in feedstock, determining factors for the behaviors of mass and metals were studied. The main findings are as follows. 
- In the ash melting processes, the ratio of IFA (incineration fly ash) in feedstock was found to be the most influential factor in determining the generation rate of MFA, i.e. the ratio of MFA increases as the ratio of fly ash increases in input. The off-gas flow rate, on the other hand, had no effect on mass distribution to MFA

- By examining the behaviors of elements, it was found that MFA in the ash melting furnace was formed mainly by the transfer of $100 \%$ of $\mathrm{Cl}, \mathrm{Na}$, and $\mathrm{K}$, and $50 \%$ of $\mathrm{Ca}$ from IFA, while $\mathrm{Si}$ was deposited to slag. Only $10 \sim 35 \%$ of $\mathrm{Ca}, \mathrm{Cl}, \mathrm{Na}$, and $\mathrm{K}$ was transferred from BA (bottom ash) to MFA. The simple assumption of the carry-over of fine particles in IFA to MFA was negated.

- A high MFA generation rate (around 30\%) in the gasification-melting system was probably caused by carry-over of fine particles, which was due to 10 to 15 times larger gas flow rate per output material and a different form of feedstock. The high content of non-volatile metal, such as $\mathrm{Al}, \mathrm{Cr}, \mathrm{Fe}$, and $\mathrm{Si}$ in MFA supported this hypothesis.

- Overall, the distribution ratio of metals could be predicted by the boiling point of each metal. Almost $100 \%$ of Cd was transferred to MFA, and $100 \%$ of $\mathrm{Fe}$, $\mathrm{Al}$, and $\mathrm{Si}$ was deposited to slag, as their boiling point suggested.

- There are two factors that change the volatility of metals: chlorine content in feedstock, and gas atmosphere. When $\mathrm{Cl}$ content in feedstock increased, up to $80 \%$ of $\mathrm{Cu}$ was transferred due to the formation of highly volatile chloride. A similar but marginal effect of $\mathrm{Cl}$ was found for $\mathrm{Pb}$. The correlation of the distribution ratio of $\mathrm{Se}$ with $\mathrm{Cl}$ content was unexplainable because both the element and chloride are volatile. The volatility of $\mathrm{Zn}$ was decreased in an oxidizing atmosphere by forming a non-volatile oxide compound.

- Distribution of metals was not different between the ash melting process and the gasification-melting process with the exception of $\mathrm{Si}, \mathrm{Al}, \mathrm{Fe}$, and $\mathrm{Cr}$. A high distribution 
ratio of such non-volatile metals to MFA in the later process, between 20 to $40 \%$ to MFA, was probably caused by the carry-over or entrainment of fine particle in the gas flow.

- The metal concentration in MFA was determined by three factors: metal content in feedstock, distribution between MFA and slag, and the dilution effect. The last factor was highly related to the MFA generation rate. By examining the relation with the MFA generation rate, the metal concentration was predominantly determined by the dilution effect to vary up to about 7 times. 


\section{Reference}

Jakob A., Stucki S., Kuhn P., 1995. Evaporation of heavy metals during the heat treatment of municipal solid waste incinerator fly ash. Environ. Sci. Technol. 29, 2429-2436.

Jung C.H., Matsuto T., Tanaka N., Okada T., 2003. Metal distribution in incineration residues of municipal solid waste (MSW) in Japan. Waste Management. (in press)

Kaneko S., 1998. Fly ash measures for hazardous material removal, stabilization, and recycling. NTS, 209-213. (in Japanese)

Kim Y.J., Matsuto T., Tanaka N., 1995. Effect of raw refuse composition on the final properties of RDF from household waste. Journal of the Japan Society of Waste Management Experts 6 (1), 7-15. (in Japanese)

Shigaki M., 2000. Incineration technology of waste. Ohmsha. (in Japanese)

Takaoka M., Takeda N., Miura S., 1997. The behavior of heavy metals and phosphorus in an ash melting process. Water Science Technology 36 (11), 275-282.

The Japan Society for Analytical Chemistry, Hokkaido Branch, 1994. Analysis of water. 151-153. (in Japanese)

The Japan Society for Chemistry, 1984. Handbook of chemistry. (in Japanese)

Yoshiie R., Nishimura M., Moritomi H., 2002. Influence of ash composition on heavy metal emission in ash melting process. Fuel 81, 1335-1340. 
Table 1. Melting and gasification-melting plants for sampling

(a) Melting

\begin{tabular}{|c|c|c|c|c|c|c|c|c|c|c|}
\hline \multirow{2}{*}{ Facility } & \multirow{2}{*}{ Furnace type } & \multirow{2}{*}{$\begin{array}{l}\text { Capacity } \\
\text { (t/d) }\end{array}$} & \multirow{2}{*}{$\begin{array}{l}\text { Furnace } \\
\text { atmosphere }\end{array}$} & \multirow{2}{*}{$\begin{array}{l}\text { Furnace } \\
\text { temp }\left({ }^{\circ} \mathrm{C}\right)\end{array}$} & \multicolumn{4}{|c|}{ Feedstock (\%) } & \multicolumn{2}{|c|}{$\begin{array}{l}\text { Ash and slag production } \\
\text { (kg/t-feedstock) }\end{array}$} \\
\hline & & & & & BA & IFA & IC & Others & MFA & Slag \\
\hline MP1 & Plasma arc & 30 & Reducing & 1,300 & 100 & - & - & - & 57 & 1006 \\
\hline MP2 & & 52 & Oxidizing & 1,350 & 100 & - & - & - & $46^{\mathrm{d}}$ & 708 \\
\hline MP3 & & 28 & Reducing & 1,300 & 69.2 & 30.8 & - & - & 392 & 700 \\
\hline MP4 & & 5 & Oxidizing & 1,400 & - & $100^{\mathrm{a}}$ & - & - & 533 & 765 \\
\hline MS1 & Surface & 24 & Oxidizing & 1,300 & 31.8 & 19.2 & - & $49^{b}$ & $60^{\mathrm{e}}$ & 693 \\
\hline MS2 & & 26 & Oxidizing & 1,350 & 74.9 & 25.1 & - & - & 191 & 799 \\
\hline MR & Electric resistance & 39 & Reducing & 1,400 & - & $94.6^{\mathrm{a}}$ & - & $5.4^{\mathrm{C}}$ & 192 & 600 \\
\hline MC & Coke bed & 15 & Reducing & 1,750 & 87.1 & - & 12.9 & - & 20 & 554 \\
\hline
\end{tabular}

BA: Bottom ash from MSW incineration, IFA: Fly ash from MSW incineration, IC: Incombustible waste,

MFA : Fly ash from ash-melting

${ }^{a}$ FA from fluidized bed incinerator

${ }^{\mathrm{b}}$ Incineration residues from old landfill

${ }^{\mathrm{c}}$ Incombustible residues remained in bottom of fluidized bed furnace

${ }^{\mathrm{d}}$ MFA was mixed with FA from incineration, so MFA generation rate of $3 \%$ to feedstock was assumed (by facility)

${ }^{\mathrm{e}}$ Water was mixed with FA to produce slurry. 50\% of moisture was assumed (by facility).

(b) Gasification-melting

\begin{tabular}{|c|c|c|c|c|c|c|c|c|}
\hline \multirow{2}{*}{ Facility } & \multirow{2}{*}{ Feedstock } & \multicolumn{2}{|c|}{ Furnace type } & \multirow{2}{*}{$\begin{array}{l}\text { Capacity } \\
\text { (t/d) }\end{array}$} & \multicolumn{2}{|c|}{ Furnace temp $\left({ }^{\circ} \mathrm{C}\right)$} & \multicolumn{2}{|c|}{$\begin{array}{l}\text { Ash and slag production } \\
\text { (kg/t-feedstock) }\end{array}$} \\
\hline & & Gasification & Melting & & Gasification & Melting & MFA & Slag \\
\hline GM1 & CW & Fluidized bed & Spiral flow & 60 & $500-600$ & 1,300 & 17 & 38 \\
\hline GM2 & CW & \multicolumn{2}{|c|}{ Shaft furnace } & 90 & \multicolumn{2}{|c|}{$300-1,700$} & 38 & 82 \\
\hline GM3 & $\mathrm{CW}+\mathrm{R}$ & Kiln furnace & Spiral flow & 210 & \multicolumn{2}{|c|}{1,300} & _ & 84 \\
\hline
\end{tabular}

CW: Combustible waste, R: Residues from bulky waste shredding facility, MFA: Fly ash from gasification-melting of MSW 
Table 2. Metal concentration in feedstock to melting

(a) Metal concentration

\begin{tabular}{|c|c|c|c|c|c|c|c|c|c|}
\hline & $\mathrm{MP}^{\mathrm{a}}{ }^{\mathrm{a}}$ & $\mathrm{MP}^{\mathrm{a}}$ & MP3 & MP4 & MS1 & MS2 & MR & $\mathrm{MC}^{\mathrm{a}}$ & Unit \\
\hline $\mathrm{Ca}$ & 26.8 & 21.6 & 30.3 & 16.7 & 29.7 & 14.5 & 27.9 & 25.8 & \multirow{5}{*}{$\%$} \\
\hline $\mathrm{Si}$ & 4.6 & 7.7 & 2.6 & 14.7 & 7.7 & 11.6 & 11.7 & 7.2 & \\
\hline $\mathrm{Cl}$ & 23.0 & 19.0 & 21.0 & 14.0 & 17.0 & 20.0 & 16.0 & 22.0 & \\
\hline $\mathrm{Na}$ & 3.6 & 4.2 & 2.2 & 3.8 & 3.2 & 3.0 & 2.3 & 4.0 & \\
\hline K & 4.1 & 6.9 & 4.1 & 3.7 & 4.9 & 3.7 & 2.5 & 5.3 & \\
\hline $\mathrm{Al}$ & 24,040 & 14,280 & 3,670 & 58,680 & 39,950 & 25,400 & 42,180 & 29,270 & \multirow{12}{*}{$\mathrm{mg} / \mathrm{kg}$} \\
\hline As & 8.0 & 3.4 & 6.8 & 1.8 & 4.4 & 2.2 & 1.7 & 21.0 & \\
\hline $\mathrm{Bi}$ & 28 & 41 & 67 & 30 & 16 & 45 & - & 25 & \\
\hline $\mathrm{Cd}$ & 58 & 97 & 111 & 39 & 44 & 90 & 185 & 104 & \\
\hline $\mathrm{Cr}$ & 73 & 104 & 58 & 192 & 89 & 47 & 93 & 120 & \\
\hline $\mathrm{Cu}$ & 549 & 932 & 632 & 6,120 & 412 & 453 & 2,520 & 740 & \\
\hline $\mathrm{Fe}$ & 6,240 & 7,930 & 2,830 & 28,200 & 6,360 & 6,370 & 12,600 & 6,900 & \\
\hline $\mathrm{Pb}$ & 2,860 & 2,900 & 3,330 & 3,440 & 1,340 & 997 & 1,260 & 9,750 & \\
\hline $\mathrm{Sb}$ & 312 & 666 & 394 & 233 & 433 & 217 & 233 & 718 & \\
\hline Se & 1.0 & 1.9 & 2 & 3.4 & 6.7 & 2.5 & 0.9 & 2.5 & \\
\hline Sn & 236 & 519 & 413 & 174 & 110 & 446 & 649 & 1,380 & \\
\hline Zn & 7,380 & 6,530 & 8,900 & 8,940 & 7,300 & 4,340 & 5,200 & 33,200 & \\
\hline \multicolumn{10}{|l|}{$\overline{B A}$} \\
\hline & MP1 & MP2 & MP3 & $\mathrm{MP}^{\mathrm{b}}$ & MS1 & MS2 & $\mathrm{MR}^{\mathrm{b}}$ & $\mathrm{MC}$ & Unit \\
\hline $\mathrm{Ca}$ & 10.8 & 14.8 & 14.5 & & 17.1 & 15.7 & & 13.8 & \multirow{5}{*}{$\%$} \\
\hline $\mathrm{Si}$ & 25.9 & 27.6 & 23.5 & & 23.9 & 23.2 & & 22.4 & \\
\hline $\mathrm{Cl}$ & 3.0 & 1.0 & 1.0 & & 2.0 & 4.0 & & 4.0 & \\
\hline $\mathrm{Na}$ & 1.9 & 2.1 & 1.9 & & 2.0 & 2.1 & & 2.0 & \\
\hline K & 0.9 & 1.3 & 1.2 & & 1.0 & 1.0 & & 0.8 & \\
\hline$\overline{\mathrm{Al}}$ & 50,870 & 29,140 & 35,480 & & 65,300 & 55,610 & & 50,100 & \multirow{12}{*}{$\mathrm{mg} / \mathrm{kg}$} \\
\hline As & 1.7 & 1.2 & 0.8 & & 0.8 & 1.6 & & 2.3 & \\
\hline $\mathrm{Bi}$ & - & - & 61 & & - & 27 & & - & \\
\hline $\mathrm{Cd}$ & 2.9 & 4.0 & 4.0 & & 2.7 & 8.0 & & 1.3 & \\
\hline $\mathrm{Cr}$ & 90 & 95 & 155 & & 109 & 93 & & 131 & \\
\hline $\mathrm{Cu}$ & 2,138 & 3,620 & 2,010 & & 730 & 3,110 & & 2,210 & \\
\hline $\mathrm{Fe}$ & 28,100 & 12,960 & 31,100 & & 26,700 & 35,800 & & 34,200 & \\
\hline $\mathrm{Pb}$ & 810 & 1,606 & 676 & & 146 & 827 & & 909 & \\
\hline $\mathrm{Sb}$ & 74 & 120 & 92 & & 66 & 79 & & 107 & \\
\hline Se & 1.1 & 2.8 & 3.0 & & 5.6 & 4.4 & & 3.5 & \\
\hline Sn & 552 & 232 & 301 & & - & 194 & & 467 & \\
\hline $\mathrm{Zn}$ & 2,900 & 3,600 & 4,620 & & 1,450 & 3,680 & & 4,130 & \\
\hline
\end{tabular}

(b) Ratio of five major elements ( $\mathrm{Ca}, \mathrm{Si}, \mathrm{Cl}, \mathrm{Na}, \mathrm{K})$ and the other metal elements $\%$ )

IFA

\begin{tabular}{lrrrrrrrr}
\hline & MP1 & MP2 & MP3 & MP4 & MS1 & MS2 & MR & MC \\
\hline Five elements & 62.1 & 59.5 & 60.1 & 53.0 & 62.4 & 52.8 & 60.5 & 64.3 \\
Other metals & 4.2 & 3.4 & 2.0 & 10.6 & 5.6 & 3.8 & 6.5 & 8.2 \\
\hline Total & 66.3 & 62.9 & 62.2 & 63.6 & 68.0 & 56.7 & 67.0 & 72.5 \\
\hline BA & & & & & & & & \\
\hline & MP1 & MP2 & MP3 & MP4 & MS1 & MS2 & MR & MC \\
\hline Five elements & 42.5 & 46.7 & 42.1 & - & 46.0 & 46.0 & - & 43.0 \\
Other metals & 8.6 & 5.1 & 7.5 & - & 9.5 & 9.9 & - & 9.2 \\
\hline Total & 51.0 & 51.9 & 49.5 & - & 55.4 & 56.0 & - & 52.2 \\
\hline
\end{tabular}

IFA: fly ash from MSW incineration, BA: bottom ash from MSW incineration

${ }^{a}$ IFA are not fed into melting furnace

${ }^{\mathrm{b}}$ Bottom ash (incombustible materials) represents a very small percentage or nil, so it is not analyzed in this study 
Table 3. Metal concentration in output products from ash melting and MSW gasification-melting

(a) Metal concentration

\begin{tabular}{|c|c|c|c|c|c|c|c|c|c|c|c|c|c|c|}
\hline & MP1 & MP2 & MP3 & MP4 & MS1 & MS2 & MR & $\mathrm{MC}$ & GM1 & GM2 & GM3(Boiler) $^{a}$ & GM3(BF1) ${ }^{b}$ & $\mathrm{GM}(\mathrm{BF} 2)^{\mathrm{C}}$ & Unit \\
\hline $\mathrm{Ca}$ & 26.0 & 20.7 & 23.6 & 14.7 & 1.2 & 26.2 & 17.4 & 3.6 & 16.0 & 24.0 & 13.7 & 9.0 & 38.4 & \\
\hline $\mathrm{Si}$ & 0.9 & 0.7 & 0.2 & 0.5 & 0.3 & 1.2 & 0.1 & 8.1 & 8.8 & 8.5 & 15.3 & 9.5 & 0.03 & \\
\hline $\mathrm{Cl}$ & 14 & 24 & 26 & 30 & 36 & 29 & 38 & 18 & 24 & 16 & 8 & 13 & 34 & $\%$ \\
\hline $\mathrm{Na}$ & 3.7 & 7.8 & 8.6 & 8.3 & 19.5 & 6.4 & 11.2 & 7.8 & 7.1 & 4.2 & 4.4 & 8.8 & 0.03 & \\
\hline $\mathrm{K}$ & 3.8 & 10.7 & 10.5 & 9.7 & 15.2 & 9.3 & 13.3 & 7.7 & 7.3 & 5.1 & 5.3 & 10.6 & 0.002 & \\
\hline $\mathrm{Al}$ & 3,920 & 1,810 & - & 3,240 & - & 4,990 & 1,740 & 11,090 & 44,890 & 39,580 & 57,490 & 37,300 & 550 & \\
\hline As & 20.9 & 118.9 & 27.2 & 7.6 & 111.2 & 7.3 & 2.4 & 103.7 & 5.4 & 3.1 & 15.1 & 79.4 & 2.3 & \\
\hline $\mathrm{Bi}$ & 75 & 95 & 53 & 80 & 30 & 20 & - & 129 & - & 4 & - & - & - & \\
\hline $\mathrm{Cd}$ & 135 & 157 & 165 & 126 & 400 & 252 & 106 & 435 & 32 & 108 & 148 & 392 & - & \\
\hline $\mathrm{Cr}$ & 46 & 232 & 18 & 50 & 121 & 18 & 9 & 345 & 390 & 113 & 568 & 618 & 8 & \\
\hline $\mathrm{Cu}$ & 5,110 & 10,670 & 3,030 & 15,160 & 3,620 & 3,700 & 3,570 & 3,200 & 2,250 & 1,520 & 785 & 1,668 & - & \\
\hline $\mathrm{Fe}$ & 2,750 & 1,640 & 2,680 & 5,040 & 1,390 & 1,990 & 2,440 & 10,860 & 11,620 & 9,450 & 15,220 & 10,360 & 203 & $\mathrm{ng} / \mathrm{kg}$ \\
\hline $\mathrm{Pb}$ & 30,000 & 23,000 & 12,810 & 9,920 & 20,300 & 7,370 & 9,580 & 66,300 & 1,640 & 2,920 & 13,910 & 34,000 & - & \\
\hline $\mathrm{Sb}$ & 968 & 954 & 393 & 362 & 952 & 878 & 234 & 294 & 353 & 267 & 1205 & 1022 & - & \\
\hline Se & 0.8 & 7.2 & 3.6 & 25.2 & 15 & 5 & 5.6 & 4.4 & 4.3 & 0.7 & 2.8 & 5.0 & 1.3 & \\
\hline Sn & 3,852 & 1,463 & 1,544 & 618 & 2,803 & 1,690 & 1,619 & 8,228 & 483 & 699 & 1,993 & 1,740 & - & \\
\hline $\mathrm{Zn}$ & 103,200 & 59,800 & 46,600 & 19,340 & 39,000 & 26,400 & 28,400 & 177,100 & 8,820 & 16,800 & 27,500 & 20,600 & 11 & \\
\hline
\end{tabular}

\begin{tabular}{|c|c|c|c|c|c|c|c|c|c|c|c|c|}
\hline & MP1 & MP2 & MP3 & MP4 & MS1 & MS2 & MR & $\mathrm{MC}$ & GM1 & GM2 & GM3 & Unit \\
\hline $\mathrm{Ca}$ & 11.4 & 14.3 & 21.6 & 21.0 & 15.8 & 21.8 & 26.0 & 22.7 & 24.7 & 26.4 & 13.6 & \multirow{5}{*}{$\%$} \\
\hline Si & 24.8 & 22.5 & 22.4 & 16.8 & 17.8 & 20.5 & 18.7 & 21.8 & 16.5 & 20.4 & 23.0 & \\
\hline $\mathrm{Cl}$ & 4.0 & 5.0 & 2.0 & 2.0 & 2.0 & 1.0 & 6.0 & 3.0 & 5.0 & 3.0 & 2.0 & \\
\hline $\mathrm{Na}$ & 4.4 & 4.0 & 2.3 & 1.5 & 2.6 & 1.8 & 0.9 & 2.9 & 1.6 & 1.9 & 4.0 & \\
\hline $\mathrm{K}$ & 1.3 & 1.3 & 0.5 & 0.3 & 1.0 & 0.7 & 0.3 & 0.9 & 0.3 & 0.4 & 1.3 & \\
\hline$\overline{\mathrm{Al}}$ & 71,650 & 54,130 & 60,910 & 89,600 & 75,070 & 83,620 & 79,490 & 71,380 & 83,840 & 83,190 & 65,960 & \multirow{12}{*}{$\mathrm{mg} / \mathrm{kg}$} \\
\hline As & 2.2 & 0.7 & 0.9 & 1 & 0.6 & 1.7 & 1.1 & 1.5 & 0.2 & 0.7 & 1.6 & \\
\hline $\mathrm{Bi}$ & 34 & - & - & 23 & - & 16 & - & - & - & 23 & - & \\
\hline $\mathrm{Cd}$ & - & - & - & - & - & - & - & - & - & - & - & \\
\hline $\mathrm{Cr}$ & 348 & 300 & 238 & 336 & 327 & 402 & 341 & 185 & 376 & 91 & 824 & \\
\hline $\mathrm{Cu}$ & 836 & 1,560 & 356 & 3,040 & 1,880 & 1,623 & 397 & 1,373 & 940 & 195 & 2,630 & \\
\hline $\mathrm{Fe}$ & 32,500 & 9,550 & 15,250 & 49,600 & 98,300 & 42,100 & 8,290 & 17,000 & 38,800 & 8,510 & 29,800 & \\
\hline $\mathrm{Pb}$ & 88 & 193 & 14 & 260 & 166 & 92 & - & - & 10 & - & 533 & \\
\hline $\mathrm{Sb}$ & - & 32 & - & 166 & 33 & 36 & - & - & 25 & 17 & 82 & \\
\hline Se & 4.3 & 1.9 & 2.7 & 0.5 & 4.4 & 2.5 & 2.1 & 0.4 & 3 & 1.3 & 1.4 & \\
\hline Sn & 240 & - & - & - & - & 397 & 243 & 235 & - & 278 & - & \\
\hline $\mathrm{Zn}$ & 1,333 & 193 & 64 & 5,980 & 2,760 & 2,670 & 1,123 & 267 & 415 & 116 & 2,320 & \\
\hline
\end{tabular}

(b) Ratio of five major elements (Ca, Si, $\mathrm{Cl}, \mathrm{Na}, \mathrm{K}$ ) and the other metal elements $\%$ )

MFA

\begin{tabular}{|c|c|c|c|c|c|c|c|c|c|c|c|c|c|}
\hline & MP1 & MP2 & MP3 & MP4 & MS1 & MS2 & MR & MC & GM1 & GM2 & GM3(Boiler) $^{a}$ & GM3(BF1) ${ }^{b}$ & $\overline{\mathrm{GM} 3(\mathrm{BF} 2)^{\mathrm{c}}}$ \\
\hline$\overline{\text { Five elements }}$ & 48.4 & 63.9 & 68.8 & 63.3 & 72.1 & 72.0 & 80.0 & 45.2 & 63.3 & 57.8 & 46.6 & 50.8 & 72.1 \\
\hline Other metals & 15.0 & 10.0 & 6.7 & 5.4 & 6.9 & 4.7 & 4.8 & 27.8 & 7.0 & 7.1 & 11.9 & 10.8 & 0.1 \\
\hline Total & 63.4 & 73.9 & 75.5 & 68.7 & 79.0 & 76.7 & 84.8 & 73.0 & 70.3 & 64.9 & 58.5 & 61.6 & 72.2 \\
\hline \multicolumn{14}{|l|}{ Slag } \\
\hline & MP1 & MP2 & MP3 & MP4 & MS1 & MS2 & MR & MC & GM1 & GM2 & GM3 & & \\
\hline Five elements & 45.9 & 47.1 & 48.7 & 41.6 & 39.2 & 45.8 & 51.9 & 51.3 & 48.1 & 52.1 & 43.8 & & \\
\hline Other metals & 10.7 & 6.6 & 7.7 & 14.9 & 17.9 & 13.1 & 9.0 & 9.0 & 12.4 & 9.2 & 10.2 & & \\
\hline Total & 56.6 & 53.7 & 56.4 & 56.5 & 57.0 & 58.9 & 60.9 & 60.3 & 60.5 & 61.3 & 54.1 & & \\
\hline
\end{tabular}

MFA: fly ash from ash melting and gasification-melting of MSW

${ }^{a}$ Boiler ash

${ }^{\mathrm{b}}$ Fly ash from the first bag filter

${ }^{c}$ Fly ash from the second bag filter 


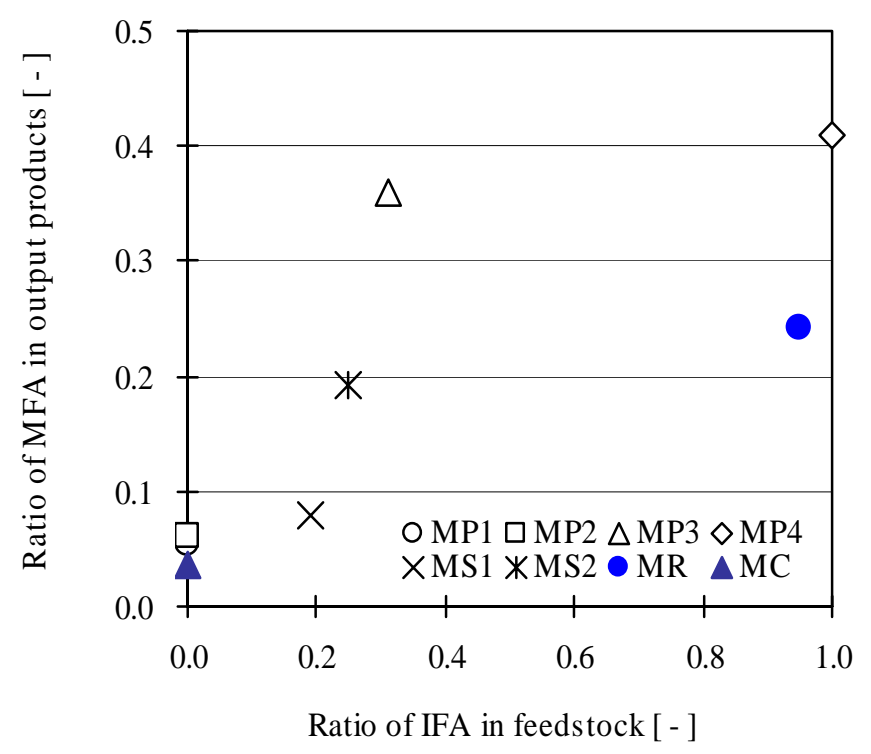

Fig. 1. Generation rate of MFA with the ratio of IFA in feedstock Generation rate of MFA $=[$ Amount of MFA $] /[$ Amount of $($ MFA+slag $)]$ 


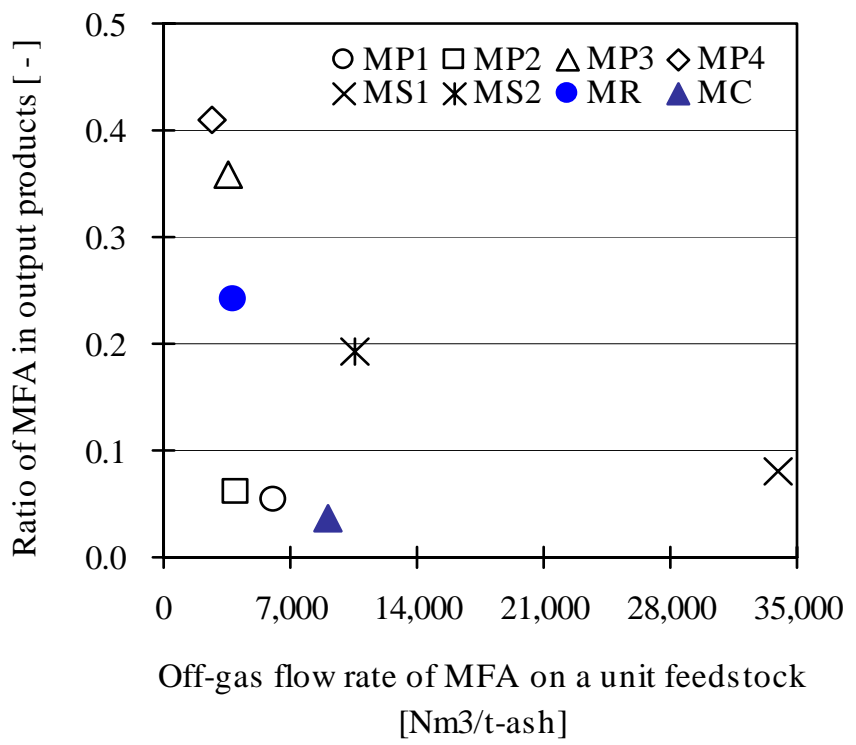

Fig. 2. Generation rate of MFA with off-gas flow rate

Generation rate of MFA = [Amount of MFA]/[Amount of (MFA+slag) $]$ 



Fig. 3. Behavior of major five elements (Ca, $\mathrm{Si}, \mathrm{Cl}, \mathrm{Na}, \mathrm{K})$ in feedstock during melting $\mathrm{X}:$ [Element mass in IFA]/[Element mass in feedstock] $\times 100[\%$ ], Feedstock=BA+IFA $\mathrm{Y}$ : [Element mass in MFA]/[Element mass in output products] $\times 100$ [ \% ], Output products=Slag+MFA

*[ ] : Facility treating incombustibles waste or incineration residues from old landfills as well as BA and IFA 


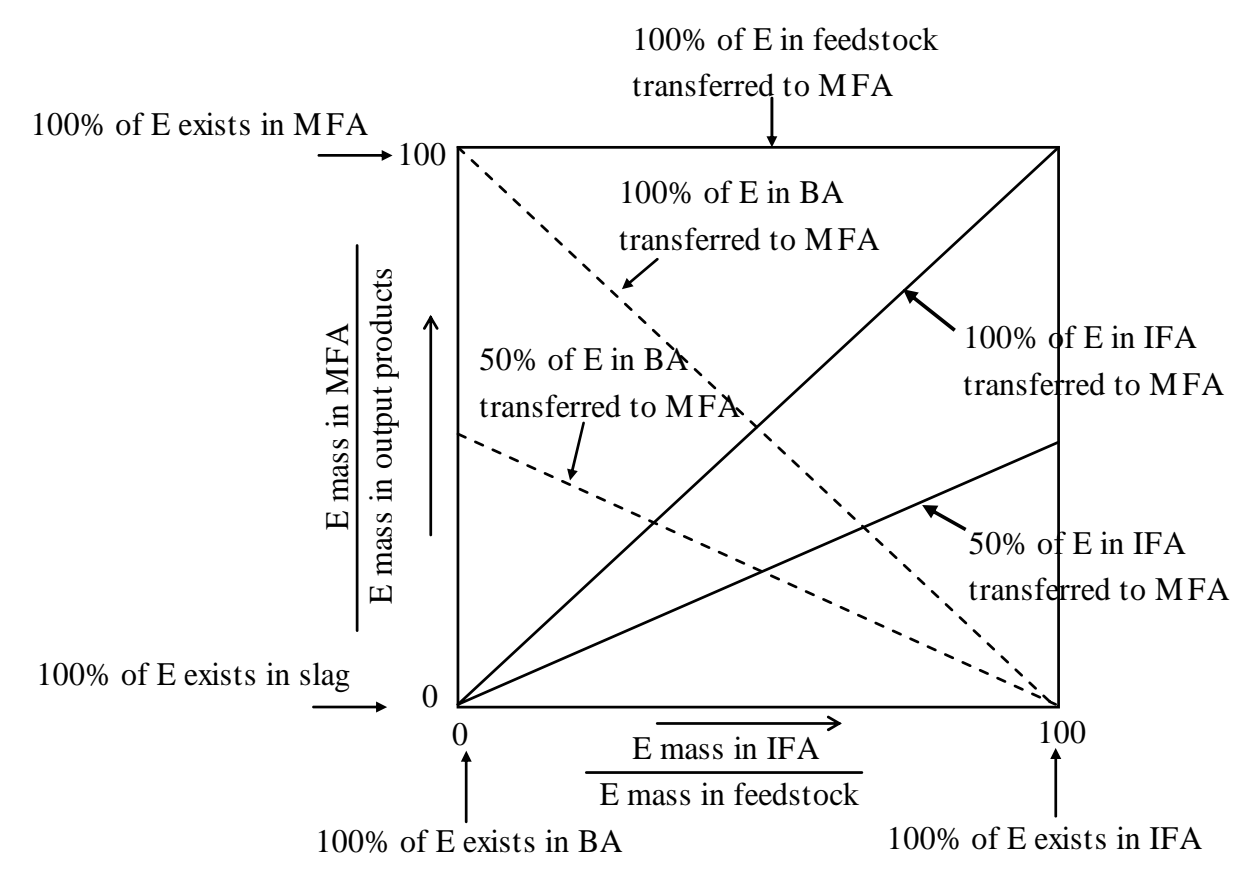

Fig. 4. Schematic diagram of mass transfer from BA and IFA to MFA

E:Element 

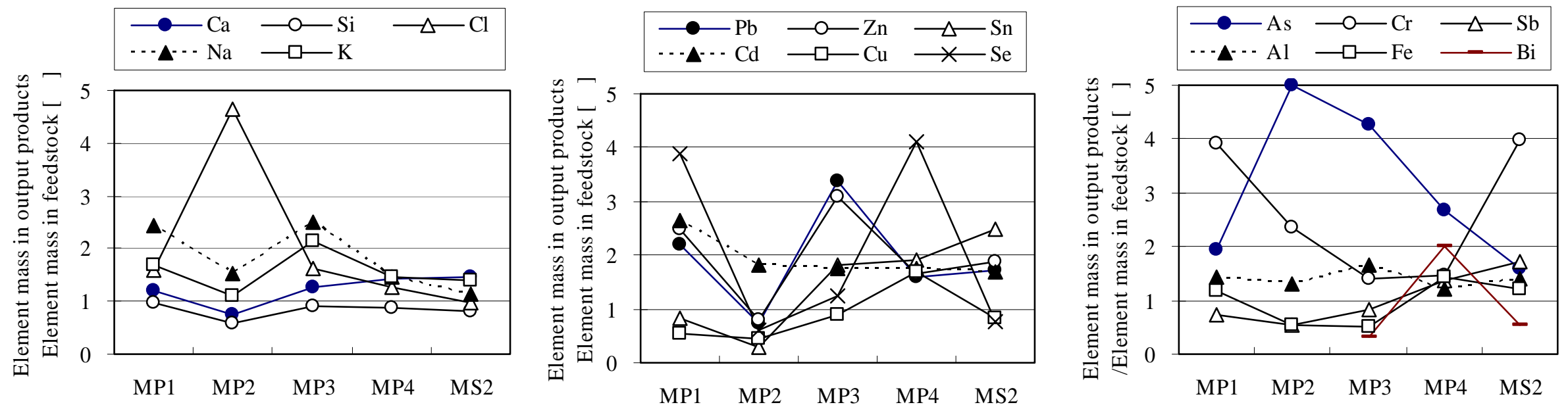

Fig. 5. Mass balance of metal elements in melting (dry basis) 
OMP1 $\square$ MP2 $\triangle \mathrm{MP} 3 \diamond \mathrm{MP} 4 \times \mathrm{MS} 1 * \mathrm{MS} 2 \bullet \mathrm{MR} \triangle \mathrm{MC}-\mathrm{GM} 1 \diamond \mathrm{GM} 2$

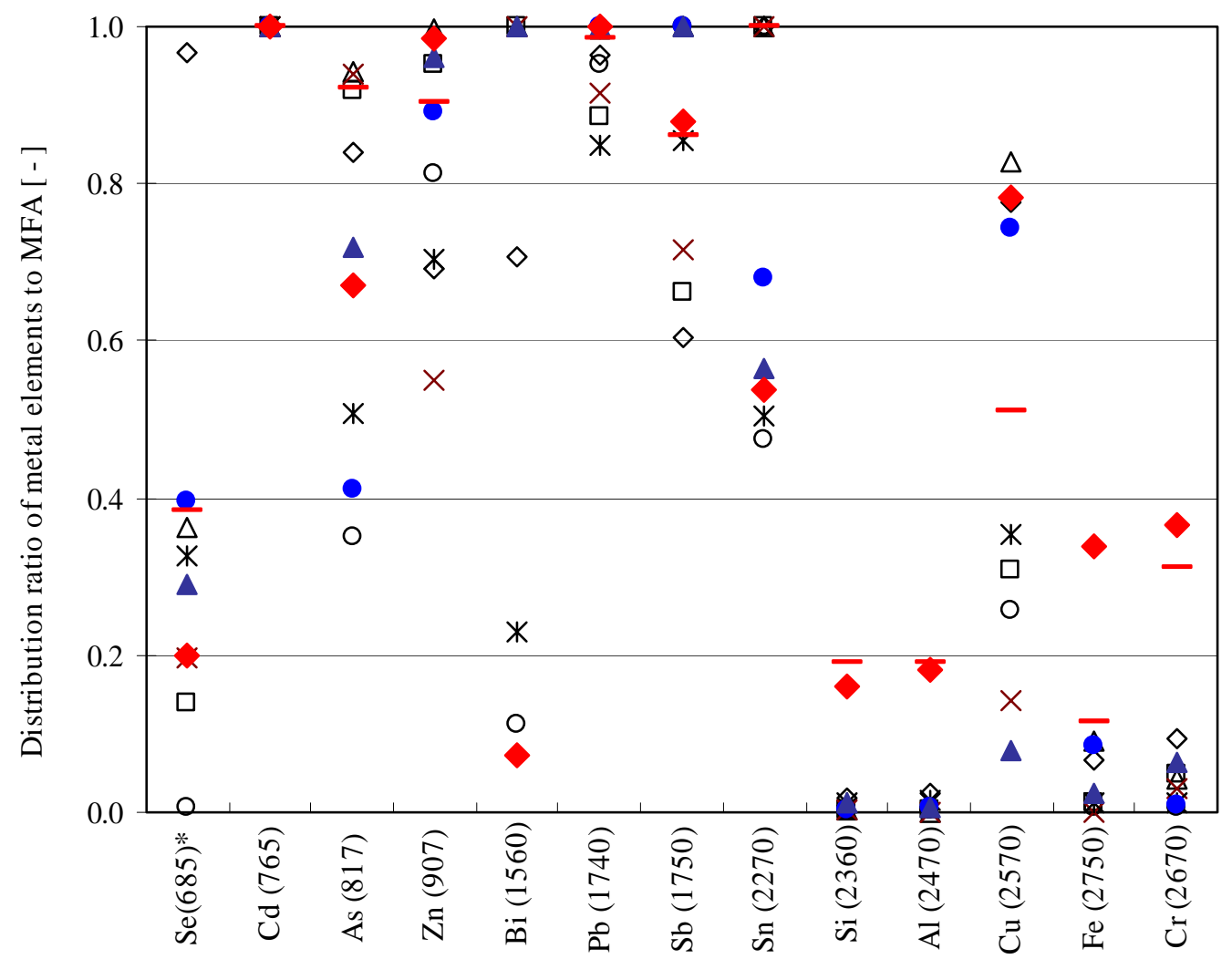

Fig. 6. Distribution ratio of metal element to MFA

$*(\quad)$ : Boiling point, ${ }^{\circ} \mathrm{C}$ 


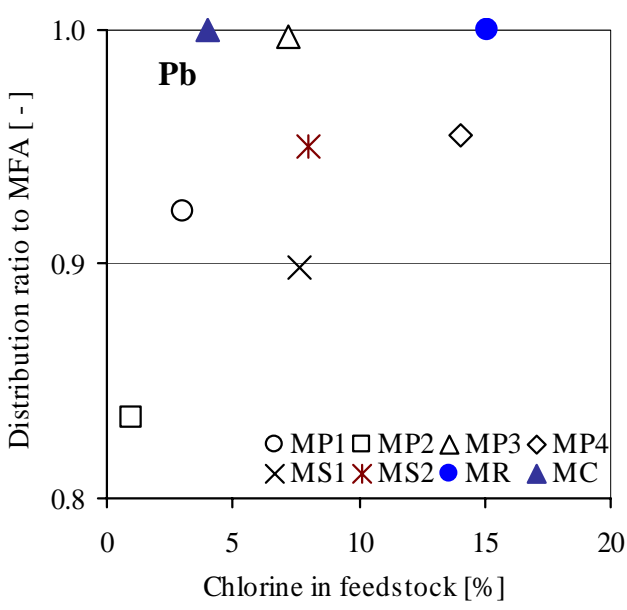

(a) $\mathrm{Pb}$

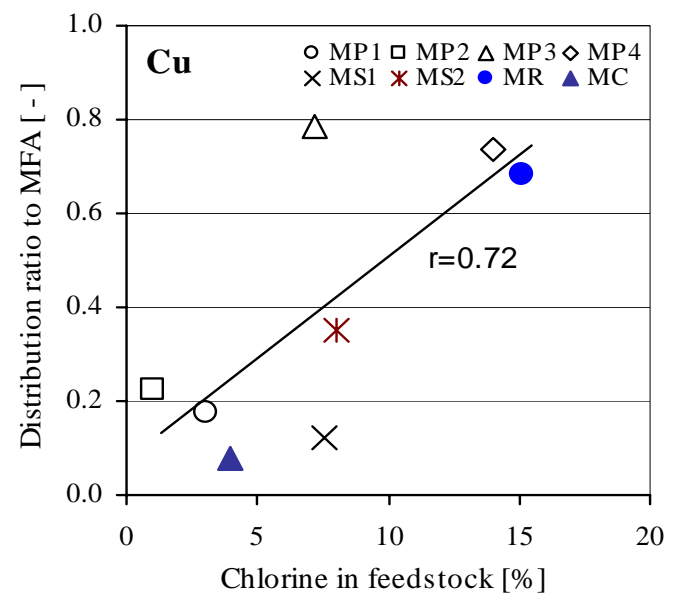

(b) $\mathrm{Cu}$

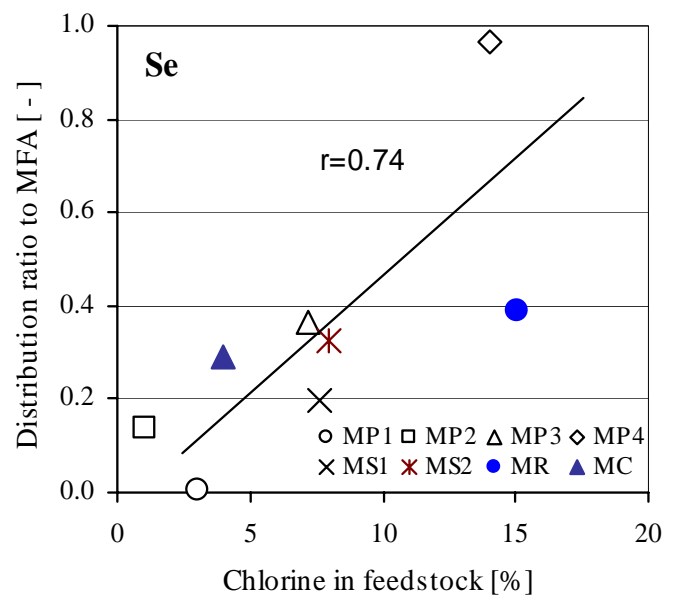

(c) $\mathrm{Se}$

Fig. 7. Distribution ratio of $\mathrm{Pb}, \mathrm{Cu}$, and Se to $\mathrm{MFA}$ with $\mathrm{Cl}$ in feedstock 

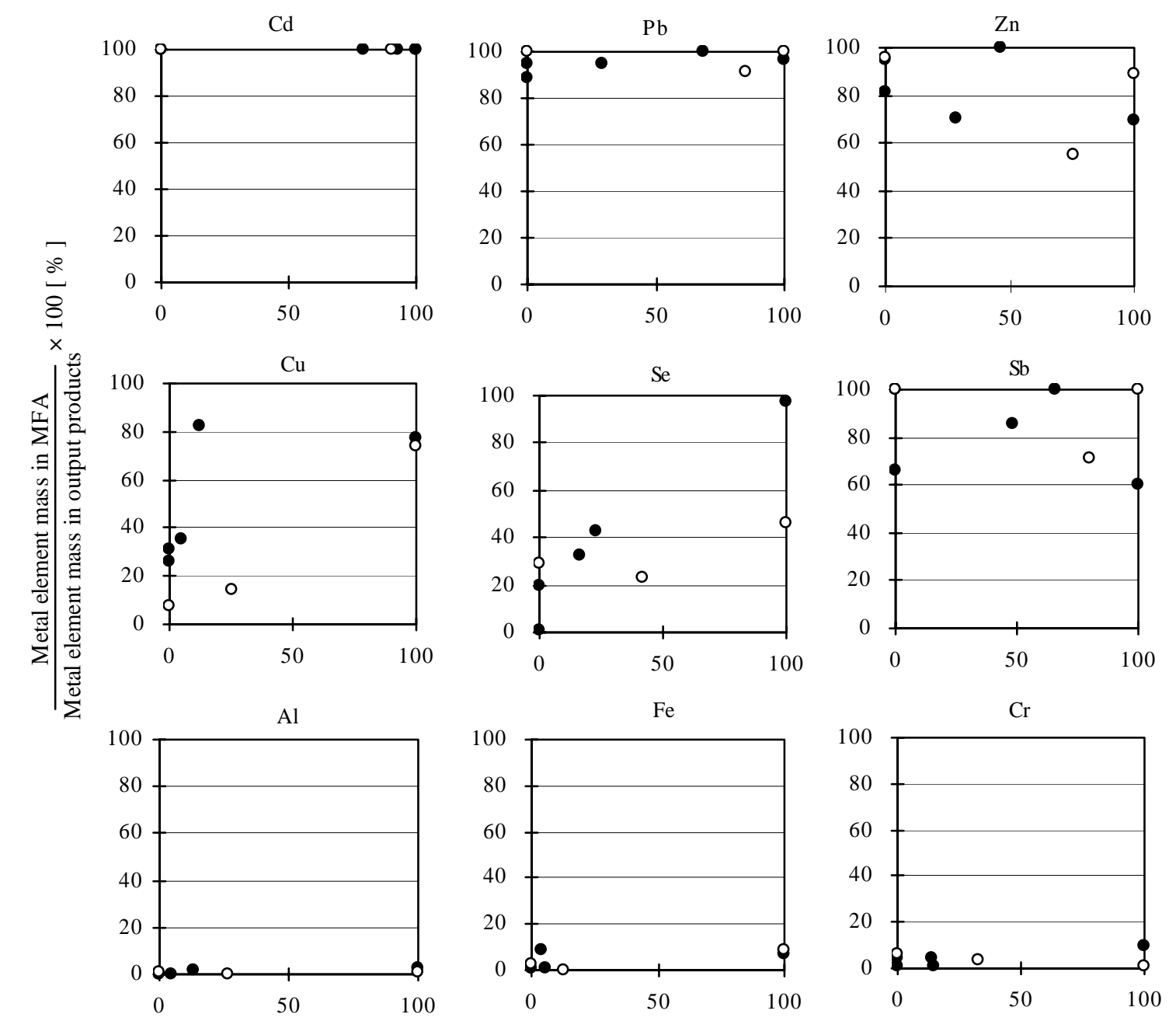

$\frac{\text { Metal element mass in IFA }}{\text { Metal element mass in feedstock }} \times 100[\%]$

Fig. 8. Behavior of metal elements in feedstock during melting

$\mathrm{X}:$ [Metal content in IFA]/[Metal content in feedstock] $\times 100$ [\%], Feedstock=BA+IFA

$\mathrm{Y}:$ [Metal content in MFA]/[Metal content in output products] $\times 100$ [\%], Output products=Slag+MFA 

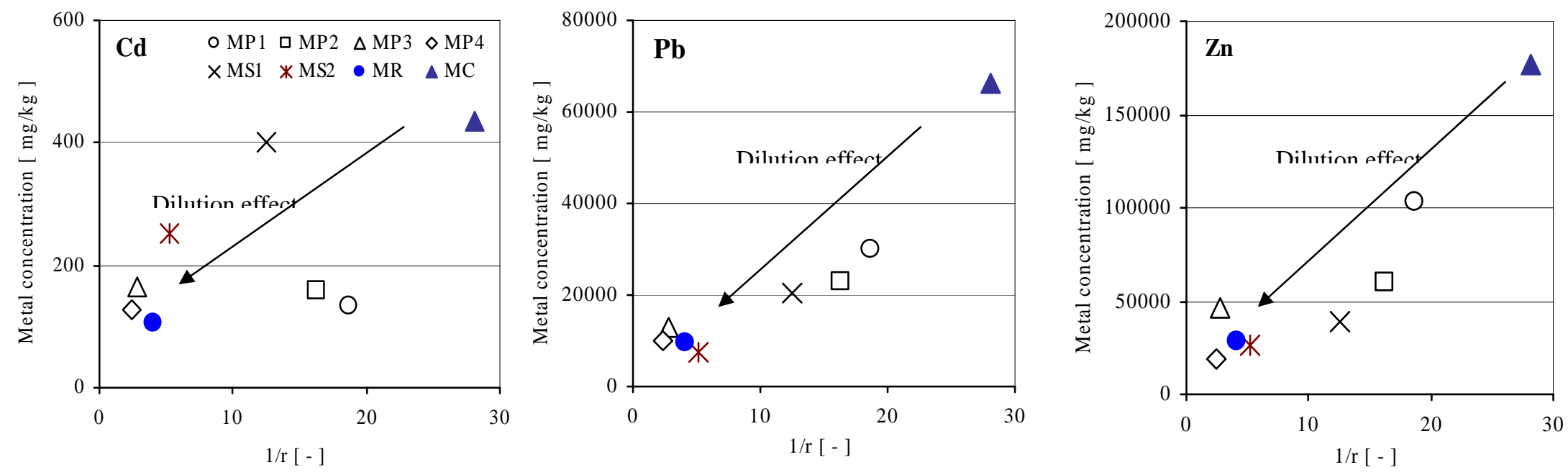

Fig. 9. Correlation between the generation rate of MFA and metal concentration in MFA

$r$ : the generation rate of MFA= the ratio of the amount of MFA to total sum of output products (MFA and slag) 